\title{
Structure and Stability of Gas Adsorption Complexes in Periodic Porous Solids as Studied by VTIR Spectroscopy: An Overview
}

\author{
Montserrat R. Delgado \\ Department of Chemistry, University of the Balearic Islands, 07122 Palma, Spain; montserrat.rodriguez@uib.es;
} Tel.: +34-971172633

Received: 3 November 2020; Accepted: 24 November 2020; Published: 30 November 2020

check for updates

\begin{abstract}
Variable-temperature infrared (VTIR) spectroscopy is an instrumental technique that enables structural characterization of gas-solid adsorption complexes by analysis of meaningful vibrational modes, and simultaneous determination of the standard enthalpy change $\left(\Delta H^{0}\right)$ involved in the gas adsorption process, which allows one to quantify the stability of the corresponding complex. This is achieved by a van't Hoff analysis of a set of IR spectra recorded over a sufficiently large temperature range. Herein, the use of this versatile spectroscopic technique is demonstrated by reviewing its application to the study of carbon monoxide, carbon dioxide and dinitrogen adsorption on several (alkaline) zeolites, which can be regarded as the archetype of periodic porous solids.
\end{abstract}

Keywords: gas adsorption; IR spectroscopy; VTIR spectroscopy; zeolites

\section{Introduction}

Gas adsorption (physisorption) in porous solids can be used in industrial processes such as oxygen (and argon) separation from air [1-4], sweetening of natural gas, upgrading of (landfill) biogas [5-8] and purification of hydrogen obtained from synthesis gas (syngas) or from steam reformation of hydrocarbons [9-11], to name only a few examples. Other (prospective) applications include post-combustion carbon dioxide capture from the flue gas of coal fired power stations [12-15], indoor air purification, e.g., in submarines and manned spacecraft [16-19], and the use of porous solids for (alternative) hydrogen or methane fuel storage and delivery in the transportation sector [20-32], including the advent of hydrogen fuelled drones and (possibly) airplanes [33-36]. For gas separation and purification the gas adsorbent units are frequently operated in a transient mode, which involves alternative gas adsorption-desorption cycles referred to as temperature swing (TSA) or pressure swing (PSA) adsorption, depending on the strategy used to regenerate the porous adsorbent $[10,13]$. Whichever the case, improvement of the gas adsorbent should be aimed at increasing differential gas adsorption capacity, while keeping the gas-solid interaction energy small enough to curb (as much as possible) the cost of adsorbent regeneration. To that end, precise knowledge about the structure and stability of the corresponding gas adsorption complex is of the utmost importance; and that is also the case when seeking the optimum porous adsorbent for gas transport and delivery. For such a purpose, classical infrared (IR) spectroscopy can give valuable structural information derived from analysis of the wavenumber shifts undergone by meaningful vibrational modes of the adsorbed molecule, and from the (relative) intensity of the corresponding IR absorption bands, but determination of the gas-solid interaction energy is out of reach unless a complementary technique (such as adsorption calorimetry) is also used. Nevertheless, the recently implemented variable-temperature IR (VTIR) spectroscopic method [37-39] facilitates direct access to both, structural characterization of the adsorption complex and (simultaneous) measurement of the standard enthalpy change $\left(\Delta H^{0}\right)$ involved in the gas adsorption process, as will be shown below by reviewing several enlightening case studies. 


\section{Background}

\subsection{Periodic Porous Solids}

In contrast to amorphous solids such as silica gel and aerogels, zeolites, periodic mesoporous silicas [40,41], metal-organic frameworks (MOFs) [42-46] and zeolite-templated porous carbons [47-51] show a regular distribution of channels and cavities that can be engineered in order to improve performance in the aforementioned technical and industrial applications. Herein, an overview of relevant developments in the field is given, keeping the focus on zeolites, which can be regarded as the archetype of periodic porous solids. Zeolites are three-dimensional aluminosilicates formed by corner sharing $\mathrm{SiO}_{4}$ and $\mathrm{AlO}_{4}$ tetrahedral units. As shown in Figure 1 (top) the framework thus formed has a negative electric charge that has to be balanced by an extra-framework cation $\left(\mathrm{M}^{+}\right)$or a proton. These charge balancing ions constitute (together with the nearby oxygen atoms) the gas adsorption centres, as shown in Figure 1. Note that the adsorbed molecule (CO in this case) can interact with the adsorption centre either through the carbon or the oxygen atom, forming the adsorption complex $\mathrm{M}^{+} \ldots \mathrm{CO}$ or $\mathrm{M}^{+} \ldots$ OC, respectively [52,53]; but the latter is known to be far less stable than the former $[54,55]$ and therefore they constitute only a very minor part of the adsorbed gas, which will not be further considered herein.

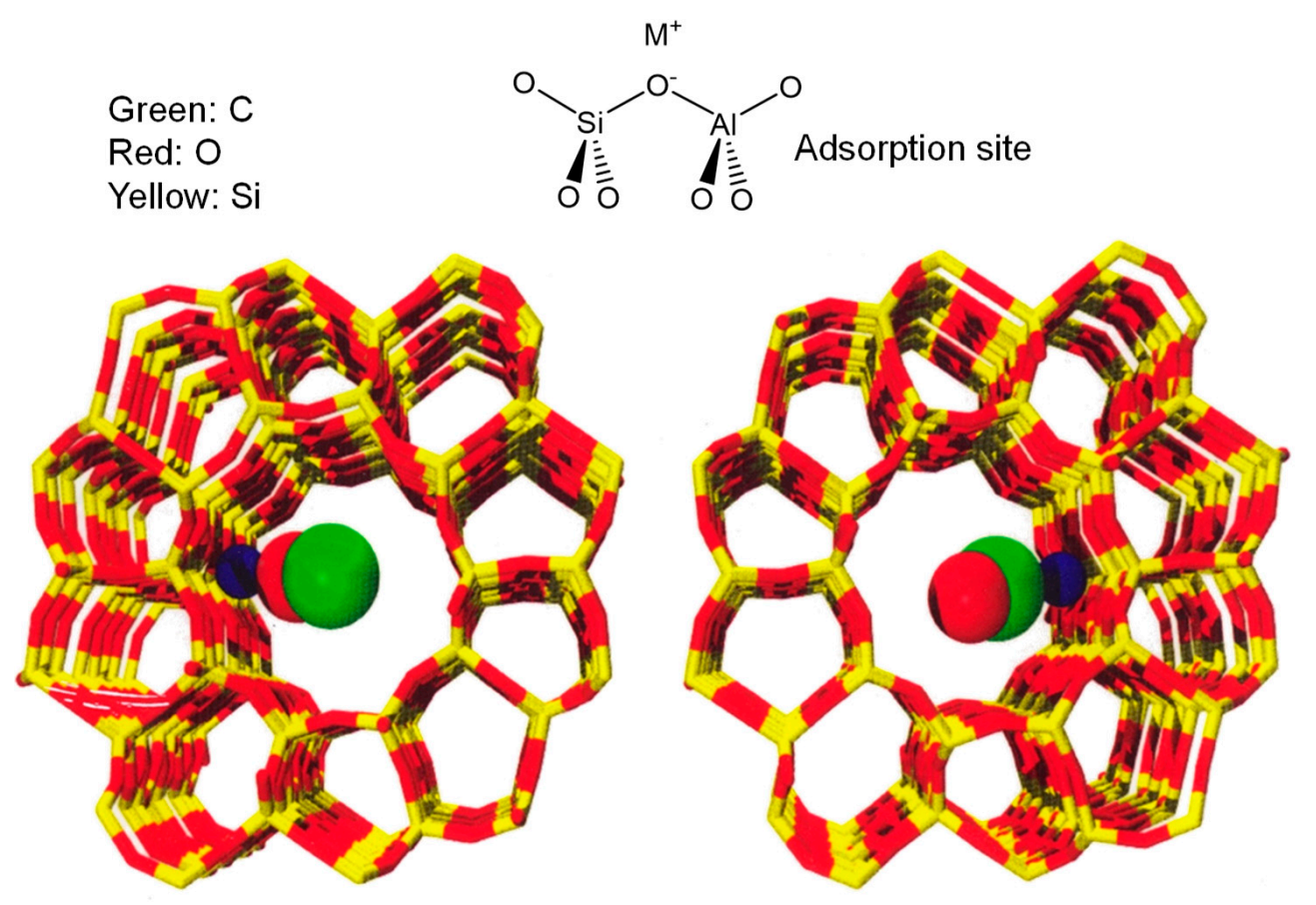

Figure 1. View along the straight channels of the Na-ZSM-5 zeolite with adsorbed CO (C and O shown in green and red, respectively).

The versatility of zeolites (both, natural and synthetic) for practical usage stems, to a large extent, from their large number of structure types, which is well over one hundred, and continues to grow by adding new synthetic members. These structure types are named using a code consisting of three capital letters, which denote the topology of each zeolite-type framework. Examples are given in Table 1 and Figure 2 [56-59]. Note that dimensionality refers to channel interconnection. 
FER
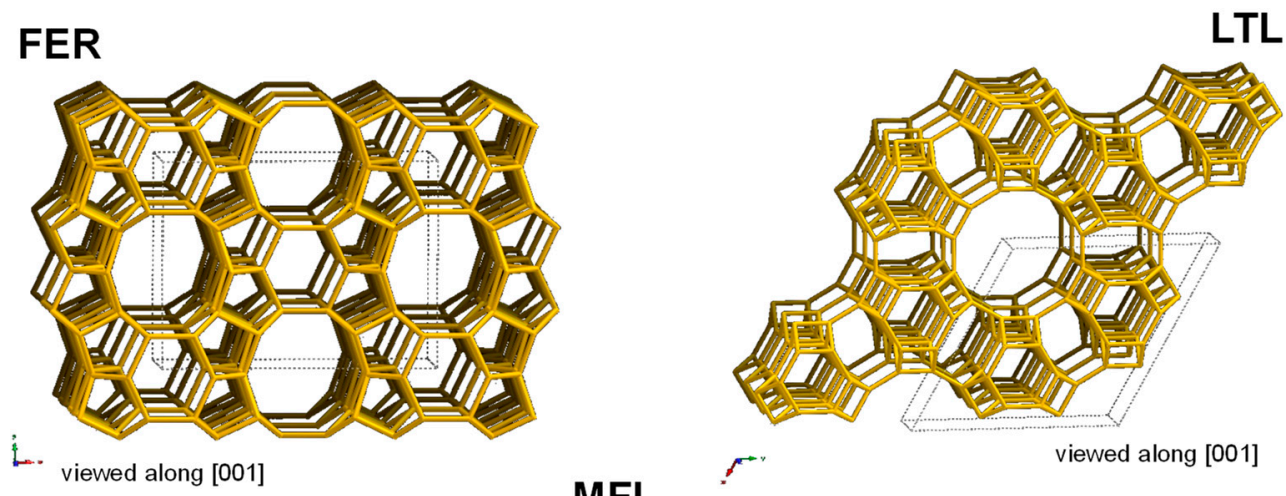

LTL

MFI

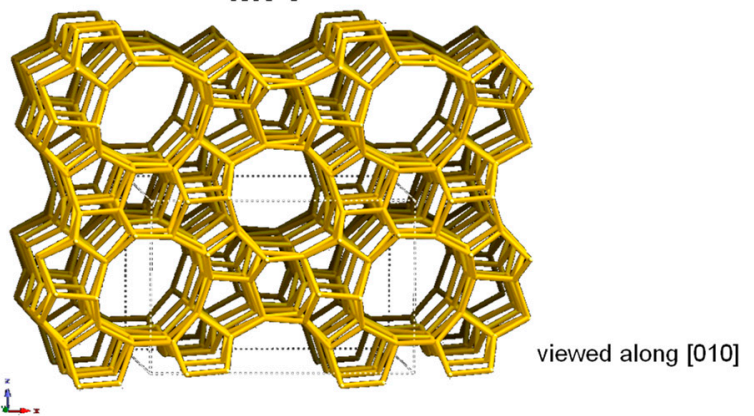

Figure 2. Framework type LTL, MFI and FER images (adapted from http://www.iza-structure.org/ databases/).

Table 1. Examples of zeolites showing the structure type-code and details on the pore system.

\begin{tabular}{cccc}
\hline Structure Type-Code & Selected Isotypes & Dimensionality & Pore Size (Å) \\
\hline Small pore & & & \\
STI & Stilbite, Stellerite & 1D & $2.7 \times 5.6$ \\
ERI & Erionite & 3D & $3.6 \times 5.1$ \\
CHA & Chabazite & 3D & 3.8 \\
LTA & Linde A & 3D & 4.1 \\
Medium pore & & & \\
FER & Ferrierite, ZSM-35 & 2D & $4.2 \times 5.4$ \\
MTT & ZSM-23, EU-13 & 1D & $4.5 \times 5.2$ \\
MFI & Silicalite, ZSM-5 & 3D & 5.5 \\
Large pore & & & \\
MOR & Mordenite, LZ-211 & 2D & $6.5 \times 7.0$ \\
LTL & Perlialite, L & 1D & 7.1 \\
FAU & Faujasite, X, Y & 3D & 7.4 \\
\hline
\end{tabular}

\subsection{Outline of the VTIR Spectroscopic Method}

The variable-temperature IR method, recently developed, is an instrumental technique particularly well suited to gain access to gas-solid physisorption thermodynamics while simultaneously obtaining the IR spectroscopic signature of the adsorption complex [38], provided that either the solid adsorbent or the molecule being adsorbed from the gas phase has an IR active mode that undergoes a change brought about by the adsorption process. Should that be the case, let Equation (1) below represent the adsorption equilibrium:

$$
\mathrm{S}_{(s)}+\mathrm{M}_{(g)} \leftrightarrows \mathrm{S} \cdots \mathrm{M}_{(a d)}
$$

where $\mathrm{S}$ stands for the adsorption site and $\mathrm{M}$ for the adsorbed molecule.

If adsorption follows the Langmuir model, the characteristic frequency of the IR absorption band being monitored does not change during adsorption measurements, and its integrated intensity is proportional to surface coverage, $\theta$, according to the Lambert Beer law, thus giving information on 
the activity (in the thermodynamic sense) of both the adsorbed species and the empty sites, $1-\theta$. Simultaneously, the equilibrium pressure, $p$, gives the activity of the molecules in the gas phase. Hence, by measuring IR absorbance and equilibrium pressure at any given temperature, $T$, the equilibrium constant $K$, of the gas adsorption process (at that temperature) can be determined. Assuming that changes in specific heat are negligible [60], the variation of $K$ with temperature, $T$, is related to the standard adsorption enthalpy, $\Delta H^{0}$, and entropy, $\Delta S^{0}$, through the van't Hoff equation:

$$
K(T)=e^{\frac{-\Delta H^{0}}{R T}} e^{\frac{\Delta S^{0}}{R}}
$$

Combination of Equation (2) with the Langmir Equation (3) leads to Equation (4) below:

$$
\begin{gathered}
\theta=\frac{K(T) p}{1+K(T) p} \\
\ln \frac{\theta}{(1-\theta) p}=\frac{-\Delta H^{0}}{R T}+\frac{\Delta S^{0}}{R}
\end{gathered}
$$

Alternatively, Equation (4) can be written as:

$$
\ln \frac{A}{\left(A_{M}-A\right) p}=\frac{-\Delta H^{0}}{R T}+\frac{\Delta S^{0}}{R}
$$

where $A$ is the actual IR absorbance being measured and $A_{\mathrm{M}}$ stands for the maximum absorbance, which corresponds to $\theta=1$. It should be clear that after determining $\theta$ (or relative IR absorbance) as a function of $T$ and $p$ over a temperature range, Equations (4) or (5) provide direct access to the corresponding values of $\Delta H^{0}$ and $\Delta S^{0}$ involved in the adsorption equilibrium process. Notably, the IR spectra should be recorded over a sufficiently wide temperature range, otherwise a spurious correlation between $\Delta H^{0}$ and $\Delta S^{0}$ can appear [61]. Further details regarding the applicability of the VTIR method can be found elsewhere [38].

On the experimental side, the VTIR method can easily be implemented by using an IR cell which allows IR spectra to be recorded over a (relatively) wide temperature range while simultaneously measuring temperature and gas equilibrium pressure. Some commercial cells can be easily adapted for such a purpose; but most of the experimental results reviewed herein were obtained with a home-made IR cell described in detail elsewhere [62]. For transmission IR spectroscopy, zeolites (pressed into the form of a thin self-supported wafer) have to be thermally activated (outgassed) under a dynamic vacuum before dosing with the gas adsorbate under study. Therefore, the IR cell needs to have a heating element for that in situ thermal activation of the zeolite wafer. Once that is done, the cell is (usually) cooled with liquid nitrogen and dosed with a (convenient) fixed amount of the gas adsorbate. After that, the cell is closed and a series of IR spectra is recorded while gradually warming it up. Note that the IR cell is thus operated as a closed system in the thermodynamic sense; in contrast to calorimetric or volumetric gas adsorption measurements, which are usually, but not always [63,64], performed in (thermodynamically) open systems.

\subsection{Theoretical Calculations}

In several of the cases reviewed herein, periodic DFT calculations were used (in combination with VTIR spectroscopy) in order to elucidate the structure of gas adsorption complexes [65]. These calculations were performed using a periodic model of the zeolite consisting of a one-unit cell or, sometimes, a double-unit cell.

In each case, DFT calculations were performed by means of the VASP program package [66-68], using the Perdew-Burke-Ernzerhof (PBE) exchange-correlation functional $[69,70]$ together with the projector augmented wave approximation (PAW) of Blöchl [70] and the plane wave basis set with a kinetic energy cut-off at $400 \mathrm{eV}$. Further details can be found elsewhere [71,72]. 


\section{Case Studies}

\subsection{Carbon Monoxide: Preliminary Considerations}

As a precaution, it should be noticed that $\mathrm{CO}$ is a very poisonous colourless, odourless and non-itching gas, which can be produced by incomplete combustion of fossil fuels, and hence inadvertent exposure to $\mathrm{CO}$ can occur when domestic fuels, such as gas or charcoal, are burned in a poorly ventilated room; exposure to car engine exhaust is another main source of concern (specially in parking garages). Carbon monoxide is very dangerous because when inhaled it binds tightly to haemoglobin, thus reducing the amount of oxygen carried by the blood stream, which can lead to severe hypoxia and, eventually, death $[73,74]$.

As already mentioned in the Introduction section, hydrogen obtained from syngas or from steam reforming of hydrocarbons usually contains traces of $\mathrm{CO}$, and has to be purified before using it in proton exchange membrane fuel cells (PMFCs), because otherwise the carbon monoxide poisons the platinum catalyst. Note that PMFCs could be used in fuel cell powered vehicles, which are a potential alternative to the current hybrid electric vehicle [75-77].

Aside from that, detailed studies on carbon monoxide adsorption are also highly valuable in the context of zeolite characterization, since $\mathrm{CO}$ is a probe molecule very frequently used for IR spectroscopic studies on the nature (and location) of the gas adsorption sites in zeolites and other porous adsorbents [65,78-82] as well as for ranking Brønsted acidity of protonic zeolites [83,84]. The early IR spectra of CO adsorbed in alkaline zeolites, usually recorded at a fixed (low) temperature, were frequently analysed assuming that the adsorption sites consisted of an extra-framework alkali-metal cation and the nearby oxygen atoms of the zeolite framework, as shown in Figure 1. More recently, however, a fruitful combination of VTIR spectroscopy with DFT calculations on periodic zeolite models $[71,85]$ led to an increasing awareness that, often, the adsorption site involves more than a single cation. Moreover, the adsorbed molecule, being confined inside intrazeolite voids (channels and cages) that have molecular dimensions can also be subject to (non-negligible) weak host-guest interactions (frequently referred to as the confinement effect) [86-89] that can affect till some extent, both the stability of gas-solid adsorption complexes and the vibrational dynamics of the adsorbed molecule [90,91].

\subsection{Carbon Monoxide Adsorption in Zeolites}

As a first example of gas adsorption in zeolites as studied by VTIR spectroscopy (combined with periodic DFT calculations) let us consider the case of $\mathrm{CO}$ adsorption in ferrierite, which is a medium pore zeolite having the framework topology depicted in Figure 2. Representative variable-temperature FT-IR spectra (in the C-O stretching region) of carbon monoxide adsorbed on a thin self-supported wafer of Na-FER having a Si:Al ratio of 8:1 are shown in Figure 3, experimental details can be found elsewhere [92]. It is important to remark, however, that surface coverage $(\theta)$ should be always kept small enough to avoid formation of dicarbonyl species [93,94], which would otherwise complicate application of the VTIR method. Main IR absorption bands are seen at 2158 and $2175 \mathrm{~cm}^{-1}$, both of them showing a hypsochromic shift of the $\mathrm{C}-\mathrm{O}$ stretching frequency $\left(2143 \mathrm{~cm}^{-1}\right.$ for free CO) as expected for an adsorption carbonyl species $\left(\mathrm{Na}^{+} \ldots \mathrm{CO}\right)$ having the dipolar $\mathrm{CO}$ molecule interacting through the carbon atom with a positively charged adsorption site $[95,96]$. By contrast, formation of an isocarbonyl complex $\left(\mathrm{Na}^{+} \ldots \mathrm{OC}\right)$ is expected to bring about a bathochromic shift of the $\mathrm{C}-\mathrm{O}$ stretching mode $[59,78,97]$, as actually shown by the very weak IR absorption band peaking at about $2115 \mathrm{~cm}^{-1}$. This isocarbonyl species is, however, a very minor feature, which will not be give further consideration herein. 


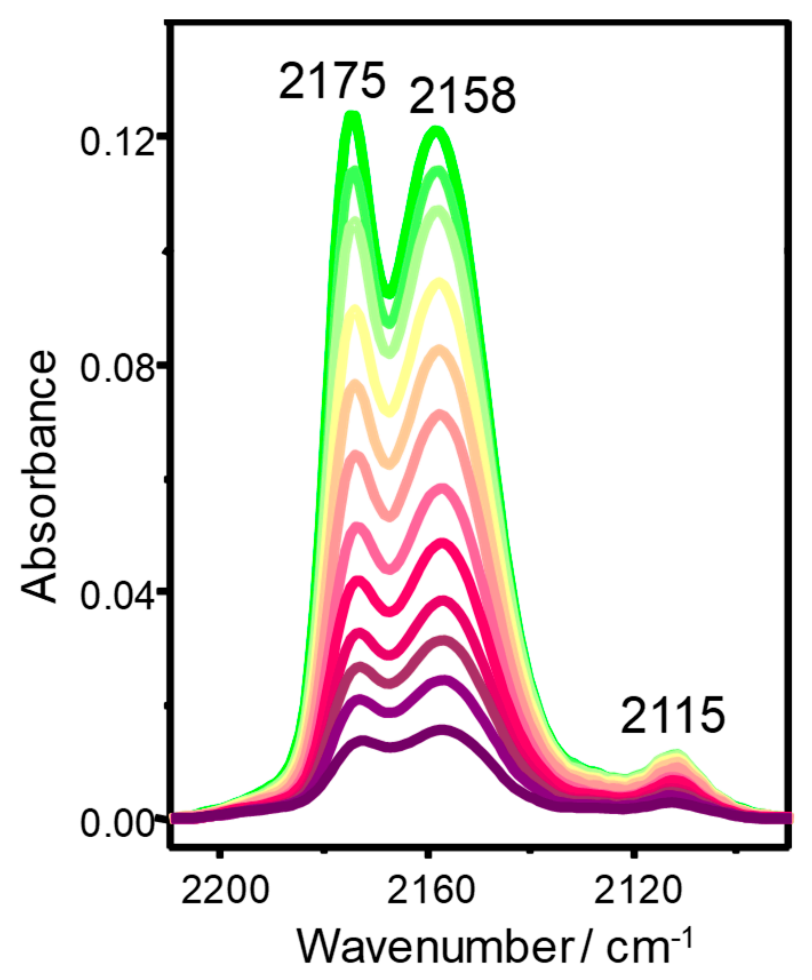

Figure 3. VTIR spectra of carbon monoxide adsorbed on Na-FER [(Si:Al) = (8:1)]. From top to bottom, temperature goes from 207 to $274 \mathrm{~K}$; and equilibrium pressure from 0.19 to $1.35 \mathrm{mbar}$ (adapted from [92]).

After computer resolution and determination of the integrated absorbance of the bands at 2158 and $2175 \mathrm{~cm}^{-1}$ in Figure 3, for the whole set of IR spectra experimentally recorded, the corresponding plots of the left-hand side of Equation (5) against the reciprocal of the temperature (van't Hoff plots) shown in Figure 4 were obtained. In each case, the needed value of $A_{\mathrm{M}}$ was obtained by refining the corresponding experimental one following the iteration procedure described elsewhere [38]. From those linear van't Hoff plots, the value of the corresponding standard adsorption enthalpy resulted to be $\Delta H^{0}=-34.6 \mathrm{~kJ} \mathrm{~mol}^{-1}$ for the adsorbed species giving rise to the band at $2158 \mathrm{~cm}^{-1}$, and $\Delta H^{0}=-30.5 \mathrm{~kJ} \mathrm{~mol}^{-1}$ for that one peaking at $2175 \mathrm{~cm}^{-1}$, which coincide (within experimental error) with the DFT calculated values of 32-35 and $29 \mathrm{~kJ} \mathrm{~mol}^{-1}$, respectively [92].

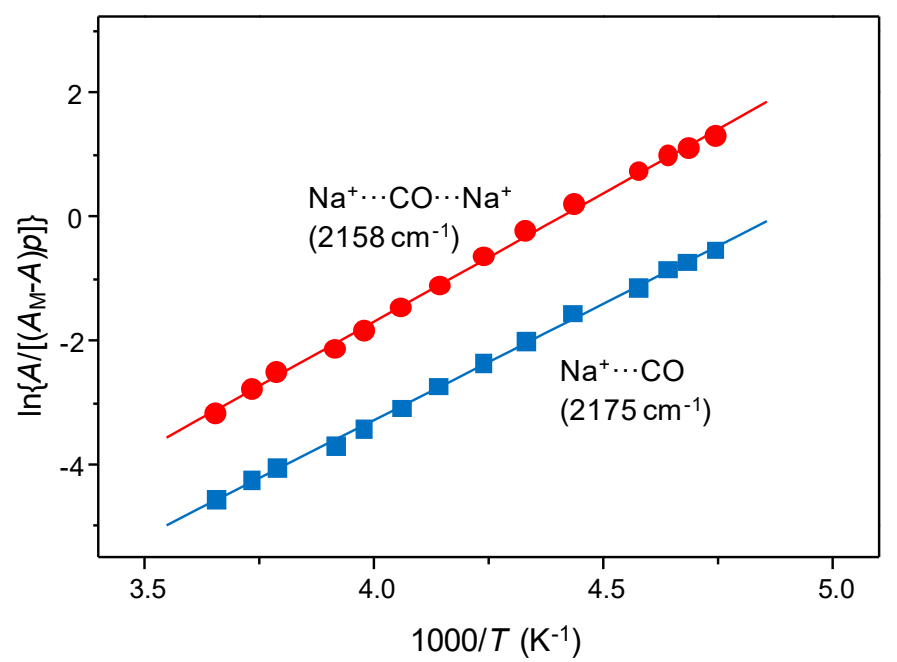

Figure 4. Van't Hoff plots corresponding to the IR absorption bands at 2175 and $2158 \mathrm{~cm}^{-1}$ in Figure 3 (adapted from [92]). 
According to those theoretical DFT calculations [92], the IR absorption band peaking at $2175 \mathrm{~cm}^{-1}$ corresponds to the $\mathrm{C}-\mathrm{O}$ stretching mode of carbon monoxide $\mathrm{C}$-bonded to $\mathrm{Na}^{+}$ions which constitute single (i.e., isolated) cation sites, as shown in Figure $5 a$ (calculated $v_{\mathrm{CO}}$ values in the range of 2174-2178 $\mathrm{cm}^{-1}$ ), while the band at $2158 \mathrm{~cm}^{-1}$ comes from adsorption complexes in which the CO molecule bridges two nearby $\mathrm{Na}^{+}$cations, which constitute a dual cation site, as shown in Figure $5 \mathrm{~b}$. It is worth of note that (in general terms) the bridged adsorption complex is usually more stable than the C-bonded complex at a single site. Nevertheless, the corresponding $v_{\mathrm{CO}}$ value is smaller for the bridged complex, because polarization of the $\mathrm{CO}$ molecule through the $\mathrm{O}$ atom partially counteracts polarization through the $\mathrm{C}$ atom. It should also be noted that the stabilization energy of the bridged $\mathrm{Na}^{+} \ldots \mathrm{CO} \cdots \mathrm{Na}^{+}$complex on a dual site is sharply dependent on the distance apart between the two cations. Calculated values [92] for both, $\mathrm{Na}^{+}$and $\mathrm{K}^{+}$are shown in Figure 6. The optimum inter-cation distance is of about 6.6 and $7.9 \AA$ for $\mathrm{Na}^{+}$and $\mathrm{K}^{+}$, respectively.
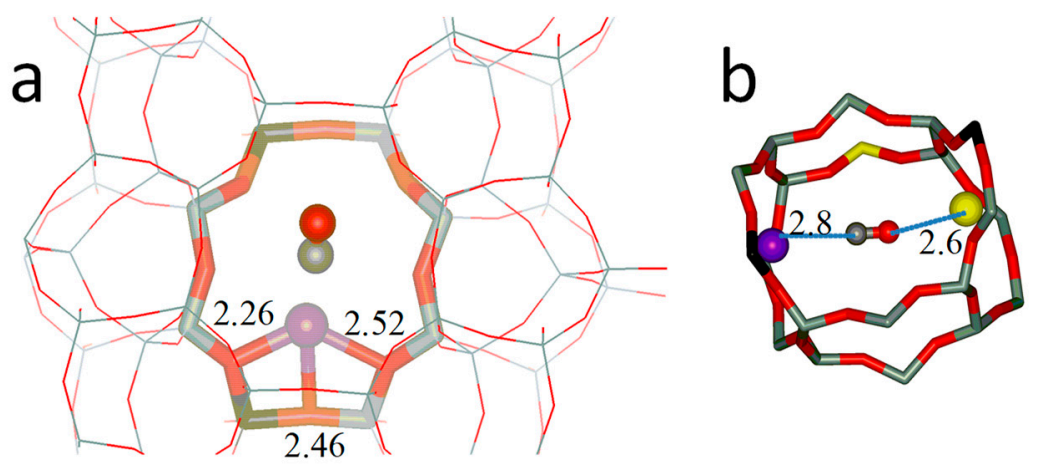

Figure 5. Carbon monoxide adsorption complexes in Na-FER; (a) single cation site and (b) dual cation site. Framework $\mathrm{Al}, \mathrm{Si}$ and $\mathrm{O}$ atoms are shown in black, grey and red sticks, respectively; the $\mathrm{C}$ and $\mathrm{O}$ atoms of $\mathrm{CO}$ are shown in grey and red balls, and $\mathrm{Na}^{+}$atoms are depicted in violet (primary cation) or yellow (secondary cation). Distances in Å units (adapted from [65]).

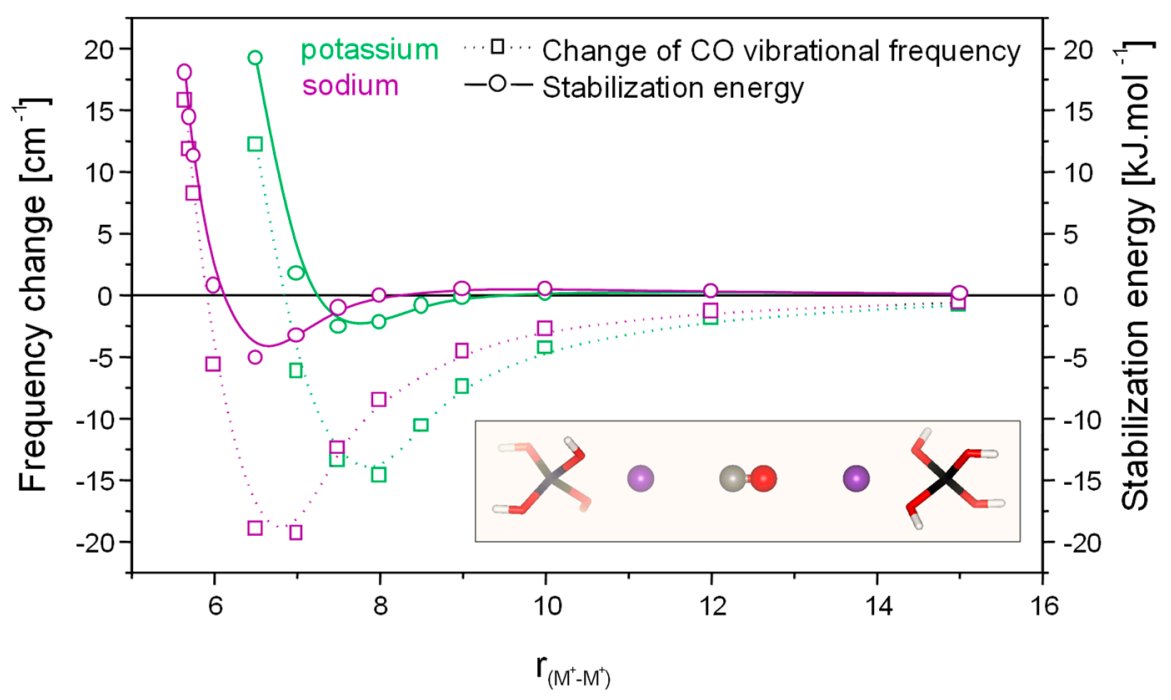

Figure 6. Dependence of stabilization energy (full line) and of change of the CO vibrational frequency (dotted line) on $\mathrm{r}(\mathrm{M}-\mathrm{M})$ distance between two $\mathrm{M}^{+}$ions; calculated using a $2 \times(1-\mathrm{T})$ cluster model (inset). Plots for $\mathrm{Na}^{+}-\mathrm{Na}^{+}$and $\mathrm{K}^{+}-\mathrm{K}^{+}$pairs depicted in violet and green, respectively (adapted from [92]).

In general terms, the relative proportion of single and dual cation sites depends on the zeolite being considered, and on the corresponding Si:Al ratio, as shown for Na-FER and K-FER in Figure 7. Zeolites having a very low Si:Al ratio (and a small unit cell) can show a more complex situation, as depicted in Figure 8 for the case of Na-A, which has the LTA structure type and a 1:1 Si to Al ratio. 
In such a case, the vast majority of adsorption sites were found to involve either 2 or $3 \mathrm{Na}^{+}$cations; the latter were termed multiple cation sites. VTIR spectroscopy, combined with DFT calculations [71], showed values of $\Delta H^{0}$ in the range of -20 to $-30 \mathrm{~kJ} \mathrm{~mol}^{-1}$ for $\mathrm{CO}$ adsorption on the dual sites, and -14 to $-28 \mathrm{~kJ} \mathrm{~mol}^{-1}$ in the case of multiple cation sites.
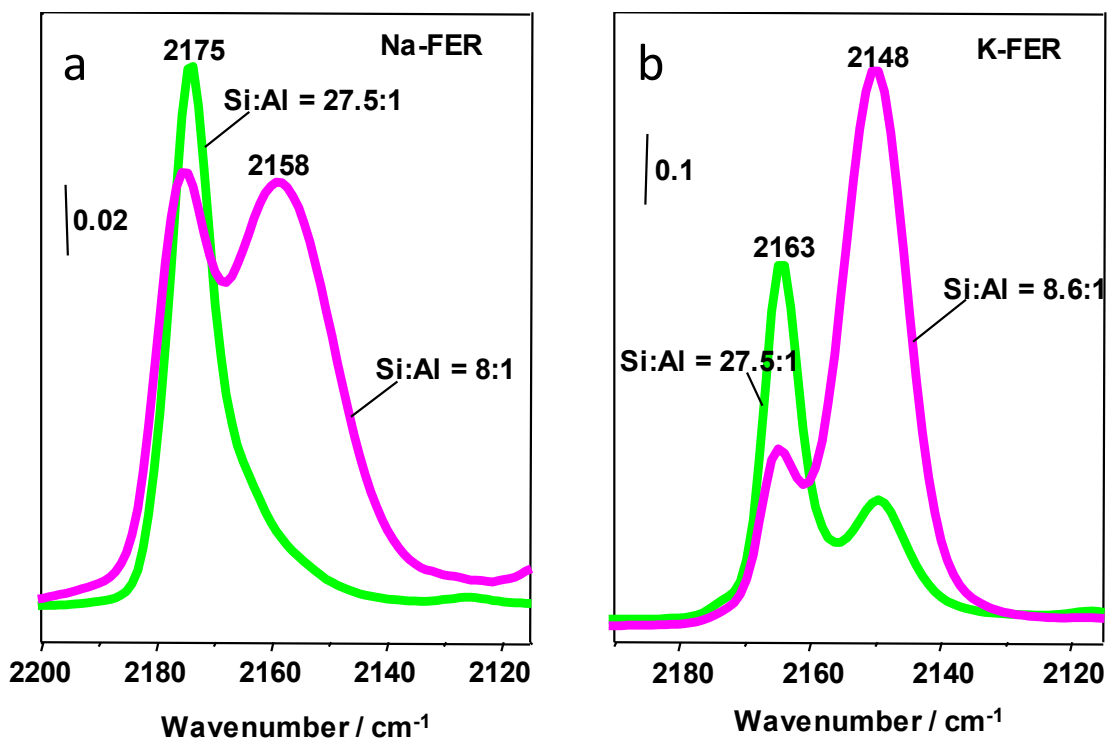

Figure 7. Effect of the Si:Al ratio on the IR spectra (at $77 \mathrm{~K}$ and comparable equilibrium pressure) of CO adsorbed on (a) Na-FER, and (b) K-FER (adapted from [92]).
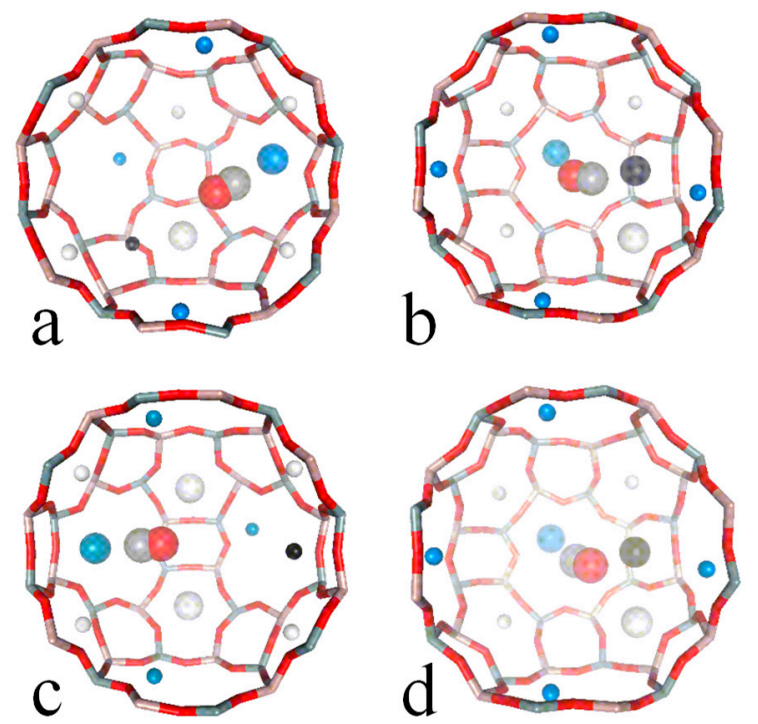

Figure 8. Carbon monoxide ( $\mathrm{C}$ in grey and $\mathrm{O}$ in red) adsorption complexes inside the supercage of zeolite $\mathrm{Na}-\mathrm{A}[(\mathrm{Si}: \mathrm{Al})=(1: 1)]$ : (a) dual cation site, $(\mathbf{b}-\mathbf{d})$ multiple cation sites. The $\mathrm{Na}^{+}$cations interacting with the CO molecule are magnified (adapted from [71]).

\subsection{Carbon Dioxide and Dinitrogen}

As already pointed out in the Introduction Section, porous adsorbents can be used, inter alia, for carbon dioxide capture from the flue gas of coal fired power stations and for indoor air purification, such as in submarines and in manned space craft. In order to remain submerged for as long as desired, nuclear submarines are equipped with electrolysers that produce oxygen from seawater, but they also need a means to capture the $\mathrm{CO}_{2}$ (present in exhaled breath) from the indoor air and pump it 
overboard. Hence the convenience to deal with both, $\mathrm{CO}_{2}$ and $\mathrm{N}_{2}$ in this section. Note that $\mathrm{O}_{2}$ is known to show a considerably weaker interaction with alkaline zeolites than $\mathrm{N}_{2}$ [98].

\subsection{1. $\mathrm{CO}_{2}$ Adsorption in K-FER}

Figure 9 shows representative VTIR spectra in the $v_{3}$ region (antisymmetric stretching) of $\mathrm{CO}_{2}$ adsorbed in a K-FER sample that had a Si:Al ratio of 27.5:1, details can be found elsewhere [99]. The main IR absorption bands, peaking at 2355 and $2346 \mathrm{~cm}^{-1}$, should clearly correspond to two different types of $\mathrm{CO}_{2}$ adsorption complexes. Further evidence comes from an isothermal (room temperature) series of IR spectra recorded at increasing $\mathrm{CO}_{2}$ dosage on a K-FER zeolite that had a Si:Al ratio of 8.6:1, which is shown in the inset to Figure 9). When compared to the corresponding gas-phase value of $\mathrm{CO}_{2}$ $\left(v_{3}=2349 \mathrm{~cm}^{-1}\right)$ the $2346 \mathrm{~cm}^{-1}$ band is red-shifted (by $-3 \mathrm{~cm}^{-1}$ ) while the other one is blue-shifted $\left(+6 \mathrm{~cm}^{-1}\right)$. Note however that $\mathrm{CO}_{2}$ confined inside the pores of silicalite (a purely siliceous zeolite) was reported to show the $v_{3}$ mode at $2341 \mathrm{~cm}^{-1}$ [100]. Taking this value as the reference, both of the $\mathrm{CO}_{2}$ adsorbed species in K-FER result to have their $v_{3}$ mode blue-shifted, by 5 and $14 \mathrm{~cm}^{-1}$, respectively.

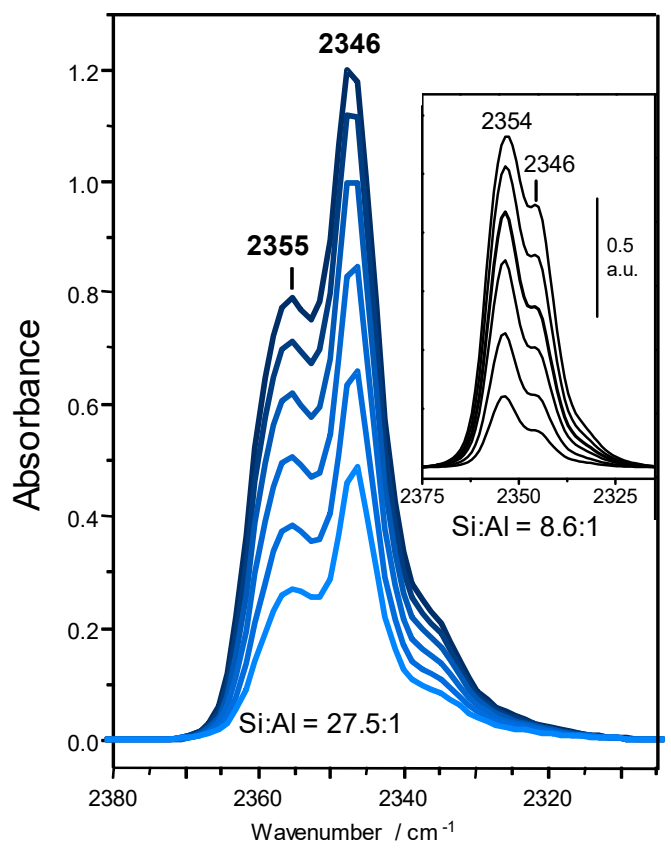

Figure 9. Representative VTIR spectra ( $v_{3}$ region) of $\mathrm{CO}_{2}$ adsorbed on K-FER [(Si:Al) = (27.5:1)]. From top to bottom, temperature goes from 268 to $301 \mathrm{~K}$; and equilibrium pressure from 0.21 to 0.50 mbar. The zeolite blank spectrum was subtracted. The inset shows IR spectra of increasing doses of $\mathrm{CO}_{2}$ adsorbed on $\mathrm{K}-\mathrm{FER}[(\mathrm{Si}: \mathrm{Al})=(8.6: 1)]$ at room temperature (adapted from [99]).

After computer resolution and determination of the integrated absorbance of the bands 2346 and $2355 \mathrm{~cm}^{-1}$ in Figure 9 (main body), the van't Hoff plots shown in Figure 10 were obtained. From these linear plots, $\Delta H^{0}$ values of -40 and $-43 \mathrm{~kJ} \mathrm{~mol}^{-1}$ for the formation of the adsorbed $\mathrm{CO}_{2}$ species giving rise to the bands at 2346 and $2355 \mathrm{~cm}^{-1}$ respectively. DFT calculations [99] gave values of $\Delta H^{0}$ in the range of -36 to $-41 \mathrm{~kJ} \mathrm{~mol}^{-1}$ for $\mathrm{CO}_{2}$ adsorbed on single cation sites ( $\mathrm{K}^{+} \ldots$ OCO species), and $-43.7 \mathrm{~kJ} \mathrm{~mol}^{-1}$ for adsorption on dual cation sites $\left(\mathrm{K}^{+} \ldots \mathrm{OCO} \cdots \mathrm{K}^{+}\right.$species), which are very close to the experimentally found values for the adsorbed species giving rise to the IR absorption bands at 2346 and $2355 \mathrm{~cm}^{-1}$, respectively. Note that, as expected, the relative amount of dual sites increases when the Si:Al ratio of the zeolite is decreased, i.e., when the concentration of $\mathrm{K}^{+}$ions increases, as shown in the inset to Figure 9. It is also noteworthy that, at a difference with $\mathrm{CO}$, the higher wavenumber band is now that one corresponding to $\mathrm{CO}_{2}$ species adsorbed on dual sites, because of the different symmetry of the adsorbed molecule. 


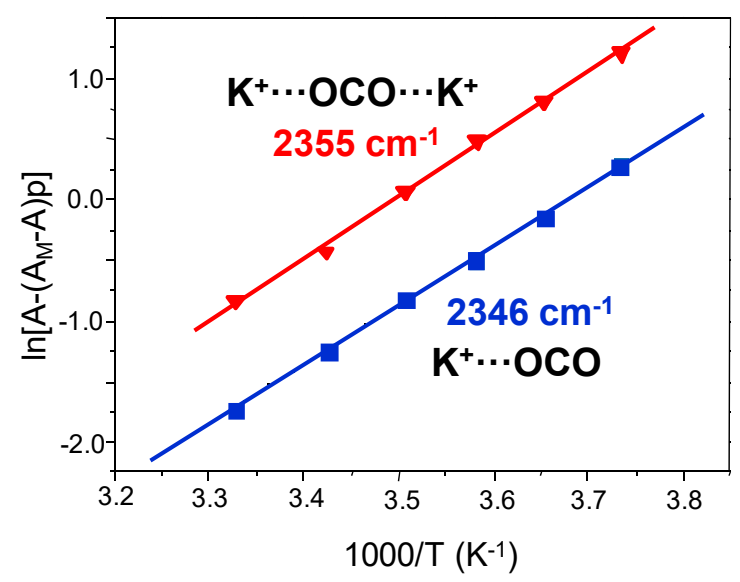

Figure 10. Van't Hoff plots corresponding to the set of IR absorption bands at 2346 (blue) and $2355 \mathrm{~cm}^{-1}$ (red) of $\mathrm{CO}_{2}$ adsorbed on K-FER (Si:Al ratio 27.5:1), shown in Figure 9 (adapted from [99]).

\subsubsection{Carbon Dioxide and Dinitrogen Adsorption in K-L}

The zeolite L (structure type LTL) has a hexagonal symmetry featuring an ordered array of parallel (1D) channels running in a direction parallel to the $c$-axis of the crystal [101]. These channels have an internal (void) diameter of about $0.75 \mathrm{~nm}$, the actual value depending slightly on the corresponding extra-framework cation.

Representative variable-temperature IR spectra of $\mathrm{CO}_{2}$ and $\mathrm{N}_{2}$ adsorbed on K-L (Si:Al ratio about 6:1) are shown in Figure 11a,b, respectively. Details on the experimental measurements can be found in ref. [102]. The $\mathrm{CO}_{2}$ adsorption complex shows a single IR absorption band centred at $2346 \mathrm{~cm}^{-1}$, which should be assigned to the antisymmetric $\left(v_{3}\right)$ vibration mode of the adsorbed molecules, as already stated above. Regarding $\mathrm{N}_{2}$, Figure $11 \mathrm{~b}$, the corresponding adsorption complex shows also a single band, which peaks at $2330 \mathrm{~cm}^{-1}$. According to previous reports [103-105] this band is assigned to the fundamental $\mathrm{N}-\mathrm{N}$ stretching mode, which becomes IR active when the molecule is perturbed by interaction with the alkali-metal cation.
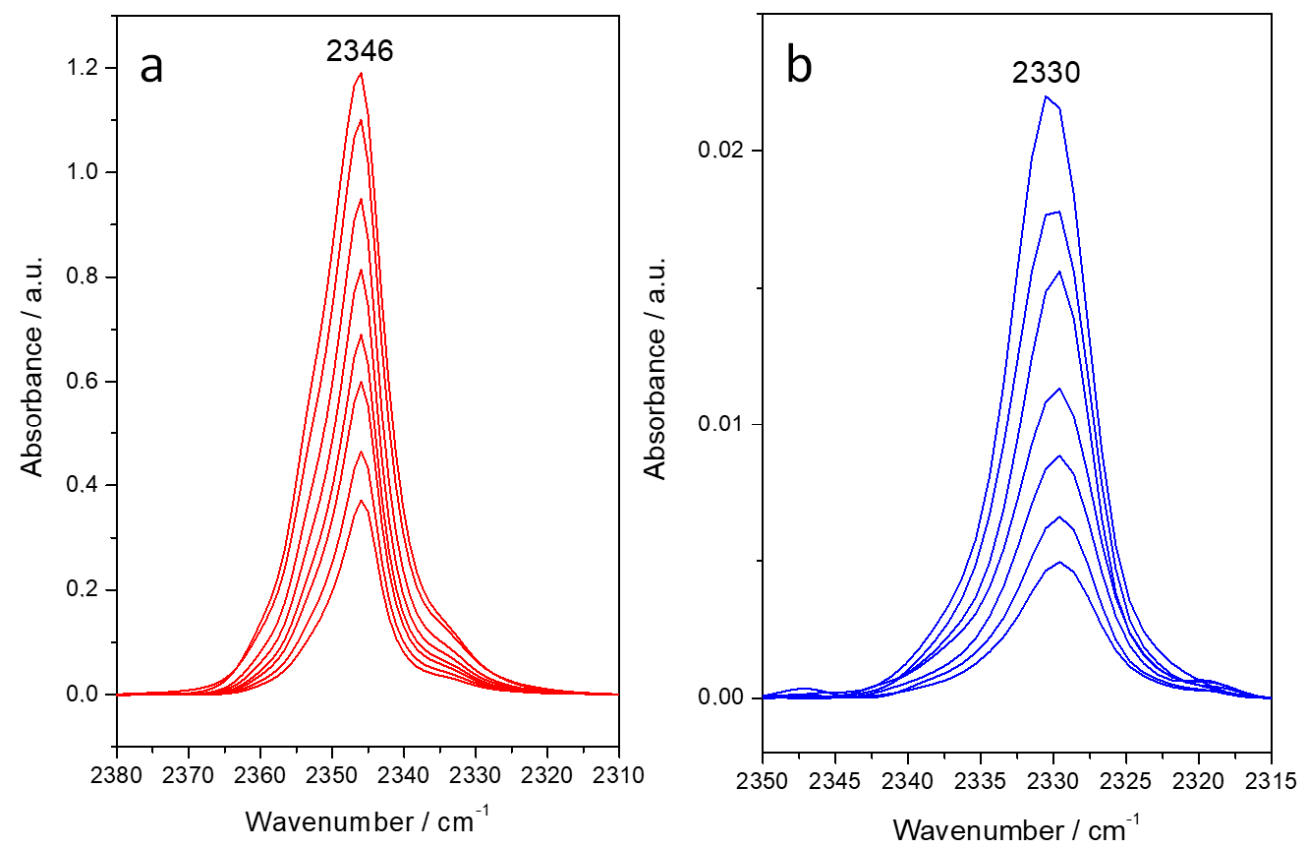

Figure 11. (a) Variable temperature FT-IR spectra (zeolite blank subtracted) in the antisymmetric $\left(v_{3}\right)$ stretching region of $\mathrm{CO}_{2}$ adsorbed on K-L. From top to bottom, temperature goes from 141 to $170 \mathrm{~K}$; 
and equilibrium pressure from 2.2 to 3.6 mbar. (b) Variable temperature FT-IR spectra (zeolite blank subtracted) in the N-N stretching region of $\mathrm{N}_{2}$ adsorbed on K-L. From top to bottom, temperature goes from 272 to $306 \mathrm{~K}$; and equilibrium pressure from 7.2 to $9.8 \mathrm{mbar}$ (adapted from [102]).

After computer integration of the full set of spectra obtained for $\mathrm{CO}_{2}$ and for $\mathrm{N}_{2}$, the corresponding van't Hoff plots depicted in Figure 12 were obtained. Those linear plots yielded the values of $\Delta H^{0}=-42.5 \mathrm{~kJ} \mathrm{~mol}^{-1}$ and $-20.6 \mathrm{~kJ} \mathrm{~mol}^{-1}$ for the adsorption enthalpy of $\mathrm{CO}_{2}$ and $\mathrm{N}_{2}$, respectively. This large difference in $\Delta H^{0}$ should facilitate efficient (thermodynamic) separation of the two gases being considered.
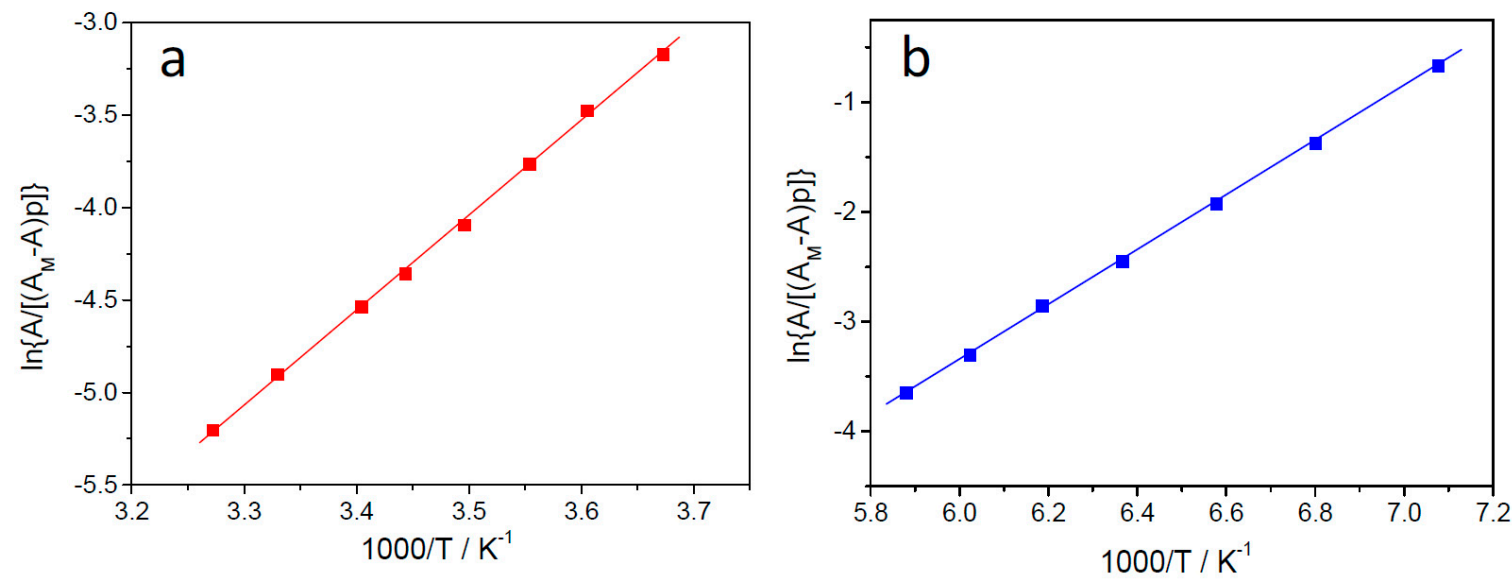

Figure 12. Van't Hoff plots derived from the IR spectra of (a) carbon dioxide, and (b) dinitrogen adsorbed on K-L. Spectra shown in Figure 11a,b, respectively (adapted from [102]).

\section{A Synopsis and Some Remarks}

On account of their periodic array of channels and cavities, which helps experimental study and tailoring of gas adsorption properties, zeolites (and several other periodic porous solids) are widely studied with a view to optimize their performance in such technical fields as gas purification, storage and transport. To that endeavour, availability of an experimental technique that enables one to determine the structure and stability of the gas adsorption complex is of the utmost importance.

By concisely reviewing a few illustrating case studies, it was demonstrated herein that the main advantage of VTIR spectroscopy over adsorption calorimetry is the fact that, (i) VTIR can be site specific, because the IR spectrum gives the finger print of the gas-adsorption complex, (ii) van't Hoff analysis of a series of IR spectra recorded over a temperature range renders the value of the standard enthalpy change, $\Delta H^{0}$, involved in the adsorption process, which monitors the stability of the adsorption complex. Moreover, zeolites often contain a small amount of extraframework aluminium species [106,107], which, by interacting with an adsorbed gas, could interfere with calorimetric measurements. Again, by being site specific, VTIR spectroscopy is likely to avoid that problem.

In addition, some of the case studies reviewed herein show how synergy between VTIR experimental results and DFT calculations leads to a very detailed knowledge about the structure of both, the zeolite adsorption sites and the corresponding gas adsorption complex; and the same strategy can be used to investigate gas adsorption in other periodic porous solids, inter alia, MOFs and several kinds of related reticular solids [45,108-111].

To the endeavour of increasing current knowledge about the structure and stability of gas adsorption complexes in zeolites, the foregoing remarks should suffice to highlight the role played by VTIR spectroscopy. Nevertheless, crystallographic methods using X-ray (or neutron) diffraction should also be mentioned [112-114]. Noteworthy is that the same van't Hoff analysis used in the VTIR method has sometimes been applied to diffraction data of gas adsorption complexes, and mutually consistent results were reported. Finally, it is also relevant to mention that variable temperature IR 
spectroscopy, combined with quantum-chemical computations, was reported to be a convenient means to analyse spin crossover transitions in transition metal ion complexes [115-117].

Funding: This research received no external funding.

Conflicts of Interest: The author declares no conflict of interest.

\section{References}

1. Mendes, A.; Costa, C.A.; RodrIn Proceedings of theigues, A.E. Oxygen separation from air by PSA: Modelling and experimental results. Sep. Purif. Technol. 2001, 24, 173-188. [CrossRef]

2. Mofarahi, M.; Towfighi, J.; Fathi, L. Oxygen Separation from Air by Four-Bed Pressure Swing Adsorption. Ind. Eng. Chem. Res. 2009, 48, 5439-5444. [CrossRef]

3. Burdyny, T.; Struchtrup, H. Hybrid membrane/cryogenic separation of oxygen from air for use in the oxy-fuel process. Energy 2010, 35, 1884-1897. [CrossRef]

4. Hamed, H.H. Oxygen separation from air using zeolite type 5A. Int. J. Sci. Eng. Res. 2015, 6, 597.

5. Zhao, X.X.; Sun, X.; Liu, X. Adsorption separation of carbon dioxide, methane and nitrogen on $\mathrm{H}$ and Na-exchanged-zeolite. J. Nat. Gas Chem. 2008, 17, 391.

6. Montanari, T.; Finocchio, E.; Salvatore, E.; Garuti, G.; Giordano, A.; Pistarino, C.; Busca, G. CO2 separation and landfill biogas upgrading: A comparison of $4 \mathrm{~A}$ and 13X zeolite adsorbents. Energy 2011, 36, 314-319. [CrossRef]

7. Tagliabue, M.; Rizzo, C.; Onorati, N.B.; Gambarotta, E.F.; Carati, A.; Bazzano, F. Regenerability of zeolites as adsorbents for natural gas sweetening: A case-study. Fuel 2012, 93, 238-244. [CrossRef]

8. Maghsoudi, H.; Soltanieh, M.; Bozorgzadeh, H.; Mohamadalizadeh, A. Adsorption isotherms and ideal selectivities of hydrogen sulfide and carbon dioxide over methane for the Si-CHA zeolite: Comparison of carbon dioxide and methane adsorption with the all-silica DD3R zeolite. Adsorption 2013, 19, 1045-1053. [CrossRef]

9. Herm, Z.R.; Swisher, J.A.; Smit, B.; Krishna, R.; Long, J.R. Metal-Organic Frameworks as Adsorbents for Hydrogen Purification and Precombustion Carbon Dioxide Capture. J. Am. Chem. Soc. 2011, 133, 5664-5667. [CrossRef]

10. Brea, P.; Delgado, J.; Águeda, V.I.; Gutiérrez, P.; Uguina, M.A. Multicomponent adsorption of H2, CH4, $\mathrm{CO}$ and $\mathrm{CO} 2$ in zeolites $\mathrm{NaX}, \mathrm{CaX}$ and $\mathrm{MgX}$. Evaluation of performance in PSA cycles for hydrogen purification. Microporous Mesoporous Mater. 2019, 286, 187-198. [CrossRef]

11. Yang, T.; Xiao, Y.; Chung, T.S. Poly-metal-benzimidazol nano-composite membrane for hydrogen purification. Energy Environ. Sci. 2011, 4, 4171. [CrossRef]

12. D.'Alessandro, D.M.; Smit, B.; Long, J.R. Carbon Dioxide Capture: Prospects for New Materials. Angew. Chem. Int. Ed. 2010, 49, 6058-6082. [CrossRef]

13. Ben-Mansour, R.; Habib, M.A.; Bamidele, O.E.; Basha, M.; Qasem, N.A.A.; Peedikakkal, A.; Laoui, T. Carbon capture by physical adsorption: Materials, experimental investigations and numerical modeling and simulations-A review. Appl. Energy 2016, 161, 225. [CrossRef]

14. Pulido, A.; Delgado, M.R.; Bludsky, O.; Rubes, M.; Nachtigall, P.; Arean, C.O. Combined DFT/CC and IR spectroscopic studies on carbon dioxide adsorption in the zeolite H-FER. Energy Environ. Sci. 2009, 2, 1187. [CrossRef]

15. Thang, H.V.; Grajciar, L.; Nachtigall, P.; Bludský, O.; Areán, C.O.; Frýdová, E.; Bulánek, R. Adsorption of CO2 in FAU zeolites: Effect of zeolite composition. Catal. Today 2014, 227, 50-56. [CrossRef]

16. Kwong, P.; Chao, C.Y.; Hui, O.K.S.; Wan, M.; Chao, C.Y.-H. Removal of VOCs from indoor environment by ozonation over different porous materials. Atmos. Environ. 2008, 42, 2300-2311. [CrossRef]

17. Liu, M.; Yang, D.; Pang, L.; Yu, Q.; Huang, Y. Experimental and computational investigation of adsorption performance of TC-5A and PSA-5A for manned spacecraft. Chin. J. Aeronaut. 2015, 28, 1583-1592. [CrossRef]

18. Li, G.; Pang, L.; Liu, M.; Yang, D.; Yu, Q.; Rong, A. Multiobjective optical method for carbon dioxide removal assembly in manned spacecraft. J. Aerosp. Eng. 2016, 29, 040016052.

19. Sidheswaran, M.A.; Destaillats, H.; Sullivan, D.P.; Cohn, S.; Fisk, W.J. Energy efficient indoor VOC air cleaning with activated carbon fiber (ACF) filters. Build. Environ. 2012, 47, 357-367. [CrossRef] 
20. Menon, V.C.; Komarneni, S. Porous Adsorbents for Vehicular Natural Gas Storage: A Review. J. Porous Mater. 1998, 5, 43-58. [CrossRef]

21. Makal, T.A.; Li, J.-R.; Lu, W.; Zhou, H.-C. Methane storage in advanced porous materials. Chem. Soc. Rev. 2012, 41, 7761-7779. [CrossRef] [PubMed]

22. Armandi, M.; Bonelli, B.; Areán, C.O.; Garrone, E. Role of microporosity in hydrogen adsorption on templated nanoporous carbons. Microporous Mesoporous Mater. 2008, 112, 411-418. [CrossRef]

23. Moellmer, J.; Moeller, A.; Dreisbach, F.; Glaeser, R.; Staudt, R. High pressure adsorption of hydrogen, nitrogen, carbon dioxide and methane on the metal-organic framework HKUST-1. Microporous Mesoporous Mater. 2011, 138, 140-148. [CrossRef]

24. Lin, K.; Adhikari, A.K.; Ku, C.-N.; Chiang, C.-L.; Kuo, H. Synthesis and characterization of porous HKUST-1 metal organic frameworks for hydrogen storage. Int. J. Hydrogen Energy 2012, 37, 13865-13871. [CrossRef]

25. Lin, K.-S.; Adhikari, A.K.; Tu, M.-T.; Wang, C.-H.; Chiang, C.-L. Preparation, characterization, and hydrogen storage capacity of MIL-53 metal-organic frameworks. J. Nanosci. Nanotechnol. 2013, 13, 2549-2556. [CrossRef]

26. Wijiyanti, R.; Gunawan, T.; Nasri, N.S.; Karim, Z.A.; Ismail, A.F.; Widiastuti, N. Hydrogen Adsorption Characteristics for Zeolite-Y Templated Carbon. Indones. J. Chem. 2019, 20, 29. [CrossRef]

27. Berg, A.W.C.V.D.; Areán, C.O. Materials for hydrogen storage: Current research trends and perspectives. Chem. Commun. 2008, 6, 668. [CrossRef]

28. Dincă, M.; Long, J.R. Hydrogen Storage in Microporous Metal-Organic Frameworks with Exposed Metal Sites. Angew. Chem. Int. Ed. 2008, 47, 6766-6779. [CrossRef]

29. Verstraete, D.; Hendrick, P.; Pilidis, P.; Ramsden, K. Hydrogen fuel tanks for subsonic transport aircraft. Int. J. Hydrogen Energy 2010, 35, 11085-11098. [CrossRef]

30. Nojoumi, H.; Dincer, I.; Naterer, G. Greenhouse gas emissions assessment of hydrogen and kerosene-fueled aircraft propulsion. Int. J. Hydrogen Energy 2009, 34, 1363-1369. [CrossRef]

31. Hames, Y.; Kaya, K.; Baltacioglu, E.; Turksoy, A. Analysis of the control strategies for fuel saving in the hydrogen fuel cell vehicles. Int. J. Hydrogen Energy 2018, 43, 10810-10821. [CrossRef]

32. Dutczak, J. Issues related to fuel cells application to small drones propulsion. IOP Conf. Ser. Mater. Sci. Eng. 2018, 421, 042014. [CrossRef]

33. Verstraete, D. Long range transport aircraft using hydrogen fuel. Int. J. Hydrogen Energy 2013, 38, 14824-14831. [CrossRef]

34. Khandelwal, B.; Karakurt, A.; Sekaran, P.R.; Sethi, V.; Singh, R. Hydrogen powered aircraft: The future of air transport. Prog. Aerosp. Sci. 2013, 60, 45-59. [CrossRef]

35. Sharpe, J.E.; Bimbo, N.; Ting, V.P.; Rechain, B.; Joubert, E.; Mays, T.J. Modelling the potential of adsorbed hydrogen for use in aviation. Microporous Mesoporous Mater. 2015, 209, 135-140. [CrossRef]

36. Lapeña-Rey, N.; Blanco, J.; Ferreyra, E.; Lemus, J.; Pereira, S.; Serrot, E. A fuel cell powered unmanned aerial vehicle for low altitude surveillance missions. Int. J. Hydrogen Energy 2017, 42, 6926-6940. [CrossRef]

37. Arean, C.O.; Manoilova, O.V.; Palomino, G.T.; Delgado, M.R.; Tsyganenko, A.A.; Bonelli, B.; Garrone, E. Variable-temperature infrared spectroscopy and access to adsorption thermodynamics of weakly interacting systems. Phys. Chem. Chem. Phys. 2002, 4, 5713. [CrossRef]

38. Garrone, E.; Areán, C.O. Variable temperature infrared spectroscopy: A convenient tool for studying the thermodynamics of weak solid-gas interactions. Chem. Soc. Rev. 2005, 34, 846-857. [CrossRef]

39. Areán, C.O. Probing Bronsted acidity of protonic zeolites with variable-temperature infrared spectroscopy. Ukr. J. Phys. 2018, 63, 538. [CrossRef]

40. Bhagiyalakshmi, M.; Yun, L.J.; Anuradha, R.; Jang, H.T. Synthesis of chloropropylamine grafted mesoporous MCM-41, MCM-48 and SBA-15 from rice husk ash: Their application to CO2 chemisorption. J. Porous Mater. 2009, 17, 475-484. [CrossRef]

41. Rao, N.; Wang, M.; Shang, Z.; Hou, Y.; Fan, G.; Li, J. CO2 Adsorption by Amine-Functionalized MCM-41: A Comparison between Impregnation and Grafting Modification Methods. Energy Fuels 2018, 32, 670-677. [CrossRef]

42. Morris, R.E.; Wheatley, P.S. Gas Storage in Nanoporous Materials. Angew. Chem. Int. Ed. 2008, 47, $4966-4981$. [CrossRef] [PubMed]

43. Bae, Y.-S.; Snurr, R.Q. Development and Evaluation of Porous Materials for Carbon Dioxide Separation and Capture. Angew. Chem. Int. Ed. 2011, 50, 11586-11596. [CrossRef] [PubMed] 
44. Maurin, G.; Serre, C.; Cooper, A.; Férey, G. The new age of MOFs and of their porous-related solids. Chem. Soc. Rev. 2017, 46, 3104-3107. [CrossRef]

45. Ferey, G. Hybrid porous solids: Past, present, future. Chem. Soc. Rev. 2008, 37, 191. [CrossRef]

46. Pettinari, C.; Tombesi, A. Metal-organic frameworks for carbon dioxide capture. In MRS Energy $\mathcal{E}$ Sustainability; Cambridge University Press: Cambridge, UK, 2020.

47. Armandi, M.; Bonelli, B.; Bottero, I.; Areán, C.O.; Garrone, E. Synthesis and characterization of ordered porous carbons with potential applications as hydrogen storage media. Microporous Mesoporous Mater. 2007, 103, 150-157. [CrossRef]

48. Nishihara, H.; Hou, P.-X.; Li, L.-X.; Ito, M.; Uchiyama, M.; Kaburagi, T.; Ikura, A.; Katamura, J.; Kawarada, T.; Mizuuchi, K.; et al. High-Pressure Hydrogen Storage in Zeolite-Templated Carbon. J. Phys. Chem. C 2009, 113, 3189-3196. [CrossRef]

49. Konwar, R.J.; De, M. Effects of synthesis parameters on zeolite templated carbon for hydrogen storage application. Microporous Mesoporous Mater. 2013, 175, 16-24. [CrossRef]

50. Youn, H.-K.; Kim, J.; Chandrasekar, G.; Jin, H.; Ahn, W.-S. High pressure carbon dioxide adsorption on nanoporous carbons prepared by Zeolite Y templating. Mater. Lett. 2011, 65, 1772-1774. [CrossRef]

51. Armandi, M.; Bonelli, B.; Karaindrou, E.; Areán, C.O.; Garrone, E. Post-synthesis modifications of SBA-15 carbon replicas: Improving hydrogen storage by increasing microporous volume. Catal. Today 2008, 138, 244-248. [CrossRef]

52. Areán, C.O.; Tsyganenko, A.A.; Platero, E.E.; Garrone, E.; Zecchina, A. Two Coordination Modes of CO in Zeolites: A Temperature-Dependent Equilibrium. Angew. Chem. Int. Ed. 1998, 37, 3161-3163. [CrossRef]

53. Tsyganenko, A.A.; Platero, E.E.; Arean, C.O.; Garrone, E.; Zecchina, A. Variable-temperature IR spectroscopic studies of CO adsorbed on Na-ZSM-5 and Na-Y zeolites. Catal. Lett. 1999, 61, 187. [CrossRef]

54. Ugliengo, P.; Garrone, E.; Ferrari, A.M.; Zecchina, A.; Arean, C.O. Quantum Chemical Calculations and Experimental Evidence for O-Bonding of Carbon Monoxide to Alkali Metal Cations in Zeolites. J. Phys. Chem. B 1999, 103, 4839-4846. [CrossRef]

55. Arean, C.O.; Manoilova, O.; Delgado, M.R.; Tsyganenko, A.; Garrone, E. Formation of several types of coordination complexes upon CO adsorption on the zeolite Li-ZSM-5. Phys. Chem. Chem. Phys. 2001, 3, 4187-4188. [CrossRef]

56. Barrer, R.M. Zeolites and Clay Minerals as Sorbents and Molecular Sieves; Academic Press: London, UK, 1978.

57. Szostak, R. Molecular Sieves: Principles of Synthesis and Identification; Van Nostrand Reinhold: New York, NY, USA, 1989.

58. Meier, W.; Olson, D.H. Altas of Zeolite Structure Types; Butterworth-Heinemann: London, UK, 1992.

59. Areán, C.O. Zeolites and Intrazeolite Chemistry: Insights from Infrared Spectroscopy. Comments Inorg. Chem. 2000, 22, 241-273. [CrossRef]

60. Garrone, E.; Areán, C.O.; Delgado, M.R.; Bonelli, B. Molar Entropy and Enthalpy of CO Adsorbed in Zeolites as Derived from VTIR Data: Role of Intermolecular Modes. ChemistryOpen 2020, 9, 599-606. [CrossRef] [PubMed]

61. Bond, G.C.; Keane, M.A.; Kral, H.; Lercher, J.A. Compensation Phenomena in Heterogeneous Catalysis: General Principles and a Possible Explanation. Catal. Rev. 2000, 42, 323-383. [CrossRef]

62. Tsyganenko, A.A.; Storozhev, P.Y.; Arean, C.O. Infrared spectroscopic studies on the binding isomerism of adsorbed molecules. Kinet. Catal. 2004, 45, 530. [CrossRef]

63. Bolis, V.; Fubini, B.; Garrone, E.; Morterra, C. Thermodynamic and vibrational characterization of CO adsorption on variously pretreated anatase. J. Chem. Soc. Faraday Trans. 1 Phys. Chem. Condens. Phases 1989, 85, 1383-1395. [CrossRef]

64. Jeremiah, D.W.; Gassensmith, J.; Gouveâ, D.; Ushakov, S.; Stoddart, J.F.; Navrotsky, A. Direct Calorimetric Measurement of Enthalpy of Adsorption of Carbon Dioxide on CD-MOF-2, a Green Metal-Organic Framework. J. Am. Chem. Soc. 2013, 135, 6790.

65. Nachtigall, P.; Delgado, M.R.; Nachtigallova, D.; Arean, C.O. The nature of cationic adsorption sites in alkaline zeolites- single, dual and multiple cation sites. Phys. Chem. Chem. Phys. 2012, 14, 1552. [CrossRef] [PubMed]

66. Kresse, G.; Hafner, J. Ab-initio molecular dynamics simulation of the liquid-metal amorphous-semiconductor transition in germanium. Phys. Rev. B 1994, 49, 14251. [CrossRef] [PubMed] 
67. Kresse, G.; Furthmüller, J. Efficiency of ab-initio total energy calculations for metals and semiconductors using a plane-wave basis set. Comput. Mater. Sci. 1996, 6, 15-50. [CrossRef]

68. Perdew, J.; Burke, K.; Ernzerhof, M. Generalized Gradient Approximation Made Simple. Phys. Rev. Lett. 1996, 77, 3865-3868. [CrossRef] [PubMed]

69. Kresse, G.; Joubert, D. From ultrasoft pseudopotentials to the projector augmented-wave method. Phys. Rev. B 1999, 59, 1758-1775. [CrossRef]

70. Blöchl, P.E. Projector augmented-wave method. Phys. Rev. B 1994, 50, 17953. [CrossRef] [PubMed]

71. Arean, C.O.; Delgado, M.R.; Bauçà, C.L.; Vrbka, L.; Nachtigall, P. Carbon monoxide adsorption on low-silica zeolites-from single to dual and to multiple cation sites. Phys. Chem. Chem. Phys. 2007, 9, 4657. [CrossRef] [PubMed]

72. Areán, C.O.; Nachtigallová, D.; Nachtigall, P.; Garrone, E.; Delgado, M.R. Thermodynamics of reversible gas adsorption on alkali-metal exchanged zeolites-the interplay of infrared spectroscopy and theoretical calculations. Phys. Chem. Chem. Phys. 2007, 9, 1421-1437. [CrossRef]

73. Kao, L.W.; Nanagas, K.A. Carbon monoxide poisoning. Emerg. Med. Clin. N. Am. 2004, 22, 985. [CrossRef] [PubMed]

74. Weaver, L.K. Carbon monoxide poisoning. N. Eng. J. Med. 2009, 360, 1217. [CrossRef]

75. Camara, G.A.; Ticianelli, E.A.; Mukerjee, S.; Lee, S.J.; McBreen, J. The CO Poisoning Mechanism of the Hydrogen Oxidation Reaction in Proton Exchange Membrane Fuel Cells. J. Electrochem. Soc. 2002, 149, A748-A753. [CrossRef]

76. Ju, J.; Lee, K.S.; Um, S. Multi-dimentional modeling of copoisoning effects on proton Exchange membrane fuel cells (PEMFCs). J. Mech. Sci. Technol. 2008, 22, 991. [CrossRef]

77. Li, Q.; He, R.; Gao, J.-A.; Jensen, J.O.; Bjerrum, N.J. The CO Poisoning Effect in PEMFCs Operational at Temperatures up to $200^{\circ} \mathrm{C}$. J. Electrochem. Soc. 2003, 150, A1599-A1605. [CrossRef]

78. Zecchina, A.; Areán, C.O. Diatomic molecular probes for mid-IR studies of zeolites. Chem. Soc. Rev. 1996, 25, 187-197. [CrossRef]

79. Knözinger, H.; Huber, S. IR spectroscopy of small and weakly interacting molecular probes for acidic and basic zeolites. J. Chem. Soc. Faraday Trans. 1998, 94, 2047-2059. [CrossRef]

80. Hadjiivanov, K.I.; Vayssilov, G.N. Characterization of oxide surfaces and zeolites by carbon monoxide as an IR probe molecule. Adv. Catal. 2002, 47, 307-511. [CrossRef]

81. Lamberti, C.; Zecchina, A.; Groppo, E.; Bordiga, S. Probing the surfaces of heterogeneous catalysts by in situ IR spectroscopy. Chem. Soc. Rev. 2010, 39, 4951-5001. [CrossRef]

82. Delgado, M.R.; De Yuso, A.M.; Bulánek, R.; Areán, C.O. Infrared spectroscopic and thermodynamic assessment of extraframework cationic adsorption sites in the zeolite K-L by using CO as probe molecule. Chem. Phys. Lett. 2015, 639, 195-198. [CrossRef]

83. Delgado, M.R.; Bulanek, R.; Chlubna, P.; Arean, C.O. Brønsted acidity of H-MCM-22 as probed by variable-temperature infrared spectroscopy of adosrbed CO and N2. Catal. Today 2014, 227, 45. [CrossRef]

84. Arean, C.O.; Delgado, M.R.; Nachtigall, P.; Thang, H.V.; Rubes, M.; Bulanek, R.; Chlubna-Eliasova, P. Measuring the Brønsted acid strength of zeolites-Does it correlate with the O-H frequency shift probed by a weak base? Phys. Chem. Chem. Phys. 2014, 15, 10129. [CrossRef]

85. Areán, C.O.; Delgado, M.R.; Frolich, K.; Bulánek, R.; Pulido, A.; Bibiloni, G.F.; Nachtigall, P. Computational and Fourier Transform Infrared Spectroscopic Studies on Carbon Monoxide Adsorption on the Zeolites Na-ZSM-5 and K-ZSM-5: Evidence of Dual-Cation Sites. J. Phys. Chem. C 2008, 112, 4658-4666. [CrossRef]

86. Ramamurthy, V.; Eaton, D.F.; Caspar, J.V. Photochemical and photophysical studies of organic molecules included within zeolites. Accounts Chem. Res. 1992, 25, 299-307. [CrossRef]

87. Derouane, E.G. Zeolites as solid solvents. J. Mol. Catal. A 1998, 134, 29. [CrossRef]

88. Gounder, R.; Iglesia, E. The catalytic activity of zeolites: Confinement effect within voids of molecular dimensions. Chem. Commun. 2013, 49, 3491. [CrossRef]

89. Polarz, S.; Kuschel, A. Chemistry in Confining Reaction Fields with Special Emphasis on Nanoporous Materials. Chem. A Eur. J. 2008, 14, 9816-9829. [CrossRef]

90. Fischer, M.; Delgado, M.R.; Areán, C.O.; Duran, C.O. CO adsorption complexes in zeolites: How does the inclusion of dispersion interactions affect predictions made from DFT calculations? The case of Na-CHA. Theor. Chem. Accounts 2015, 134, 91. [CrossRef] 
91. Nachtigallová, D.; Bludský, O.; Areán, C.O.; Bulánek, R.; Nachtigall, P. The vibrational dynamics of carbon monoxide in a confined space-CO in zeolites. Phys. Chem. Chem. Phys. 2006, 8, 4849-4852. [CrossRef]

92. Nachtigall, P.; Delgado, M.R.; Frolich, K.; Bulánek, R.; Palomino, G.T.; Bauçà, C.L.; Arean, C.O. Periodic density functional and FTIR spectroscopic studies on CO adsorption on the zeolite Na-FER. Microporous Mesoporous Mater. 2007, 106, 106-162. [CrossRef]

93. Hadjiivanov, K.; Massiani, P.; Knözinger, H. Low-temperature CO and 15N2 adsorption and co-adsorption on alkali cation exchanged EMT zeolites: An FTIR study. Phys. Chem. Chem. Phys. 1999, 1, 3831-3838. [CrossRef]

94. Hadjiivanov, K.; Knözinger, H. FTIR study of the low-temperature adsorption and co-adsorption of CO and N2 on NaY zeolite: Evidence of simultaneous coordination of two molecules to one Na+ site. Chem. Phys. Lett. 1999, 303, 513-520. [CrossRef]

95. Hush, N.S.; Williams, M.L. Carbon monoxide bond-length, force constant and infrared intensity variations in strong electric fields: Valence shell calculations, with applications to properties of adsorbed and complexed CO. J. Mol. Spectrosc. 1974, 50, 349. [CrossRef]

96. Lamberti, C.; Bordiga, S.; Geobaldo, F.; Zecchina, A.; Areán, C.O. Stretching frequencies of cation-CO adducts in alkali-metal exchanged zeolites: An elementary electrostatic approach. J. Chem. Phys. 1995, 103, 3158-3165. [CrossRef]

97. Storozhev, P.; Yanko, V.; Tsyganenko, A.; Palomino, G.T.; Delgado, M.R.; Arean, C.O. Isomeric states of polar molecules on ionic surfaces: Electrostatic model and FTIR studies. Appl. Surf. Sci. 2004, 238, 390-394. [CrossRef]

98. Dunne, J.A.; Rao, M.; Sircar, S.; Gorte, R.J.; Myers, A.L. Calorimetric heats of adsorption and adsorption isotherms. 2. O2, N2, Ar, CO2, CH4, C2H6 and SF6 on NaX, H-ZSM-5, and Na-ZSM-5 zeolites. Langmuir 1996, 12, 5896. [CrossRef]

99. Arean, C.O.; Delgado, M.R.; Bibiloni, G.F.; Bludsky, O.; Nachtigall, P. Variable-Temperature IR Spectroscopic and Theoretical Studies on CO2 Adsorbed in Zeolite K-FER. ChemPhysChem 2011, 12, 1435-1443. [CrossRef]

100. Bonelli, B.; Civalleri, B.; Fubini, B.; Ugliengo, P.; Arean, C.O.; Garrone, E. Experimental and quantum-chemical studies on the adsorption of carbon dioxide in alkali-metal-exchanged ZSM-5 zeolites. J. Phys. Chem. B 2000, 104, 10978. [CrossRef]

101. Meir, W.M.; Olson, D.H. Atlas of Zeolite Structure Types; Butterworth: London, UK, 1987.

102. Arean, C.O.; Bibiloni, G.; Delgado, M.R. FT-IR spectroscopic and thermodynamic study on the adsorption of carbon dioxide and dinitrogen in the alkaline zeolite K-L. Appl. Surf. Sci. 2012, 259, 367-370. [CrossRef]

103. Förster, H.; Schuldt, M. Infrared active fundamentals of deuterium, nitrogen, and oxygen in zeolitic matrices. J. Chem. Phys. 1977, 66, 5237. [CrossRef]

104. Bulanin, K.M.; Lobo, R.F.; Bulanin, M.O. Low temperature adsorption of N2, O2 and D2 on LiX, NaX and NaLiX zeolites studied by FT-IR spectroscopy. J. Chem. Phys. B 2000, 104, 1269. [CrossRef]

105. Delgado, M.R.; Areán, C.O. Non-Linear Enthalpy-Entropy Correlation for Nitrogen Adsorption in Zeolites. Molecules 2018, 23, 2978. [CrossRef]

106. Zecchina, A.; Bordiga, S.; Spoto, G.; Scarano, D.; Petrini, G.; Leofanti, G.; Padovan, M.; Areán, C.O. Low-temperature Fourier-transform infrared investigation of the interaction of CO with nanosized ZSM5 and silicalite. J. Chem. Soc. Faraday Trans. 1992, 88, 2959-2969. [CrossRef]

107. Delgado, M.R.; Bulanek, R.; Arean, C.O. Answer to the comment by O. Cairon on "Brønsted acidity of H-MCM-22 as probed by variable-temperature infrared spectroscopy of adosrbed CO and N2". Catal. Today 2015, 252, 214. [CrossRef]

108. Valenzano, L.; Civalleri, B.; Chavan, S.; Palomino, G.T.; Arean, C.O.; Bordiga, S. Computational and Experimental Studies on the Adsorption of CO, N2, and CO2 on Mg-MOF-74. J. Phys. Chem. C 2010, 114, 11185-11191. [CrossRef]

109. Gropp, C.; Canossa, S.; Wuttke, S.; Gándara, F.; Li, Q.; Gagliardi, L.; Yaghi, O.M. Standard Practices of Reticular Chemistry. ACS Central Sci. 2020, 6, 1255-1273. [CrossRef]

110. Civalleri, B.; Maurin, G.; Van Speybroeck, V. Frontiers in modeling metal-organic frameworks. Adv. Theory Simul. 2019, 2, 1900196. [CrossRef]

111. Getman, R.B.; Bae, Y.-S.; Wilmer, C.E.; Snurr, R.Q. Review and Analysis of Molecular Simulations of Methane, Hydrogen, and Acetylene Storage in Metal-Organic Frameworks. Chem. Rev. 2012, 112, 703-723. [CrossRef] 
112. Rzepka, P.; Bacsik, Z.; Smeets, S.; Hansen, T.C.; Hedin, N.; Wardecki, D. Site-Specific Adsorption of CO2 in Zeolite NaK-A. J. Phys. Chem. C 2018, 122, 27005-27015. [CrossRef]

113. Conterosito, E.; Palin, L.; Caliandro, R.; Van Beek, W.; Chernyshov, D.; Milanesio, M. CO2 adsorption in Y zeolite: A structural and dynamic view by a novel principal-component-analysis-assisted in situ single-crystal X-ray diffraction experiment. Acta Crystallogr. Sect. A Found. Adv. 2019, 75, 214-222. [CrossRef]

114. Rzepka, P.; Wardecki, D.; Smeets, S.; Müller, M.; Gies, H.; Zou, X.; Hedin, N. CO2-Induced Displacement of $\mathrm{Na}+$ and $\mathrm{K}+$ in Zeolite $|\mathrm{NaK}|-\mathrm{A}$. J. Phys. Chem. C 2018, 122, 17211-17220. [CrossRef]

115. Griaznova, T.P.; Katsyuba, S.A.; Shakirova, O.G.; Lavrenova, L.G. Variable temperature IR spectroscopy and quantum chemistry as the tool for diagnostics of metal spin state. Chem. Phys. Lett. 2010, 495, 50. [CrossRef]

116. Herber, R.; Casson, L.M. ChemInform Abstract: Light-Induced Excited-Spin-State Trapping: Evidence from VTFTIR Measurements. Chem. Inf. 1986, 17, 847. [CrossRef]

117. Neya, S.; Takahashi, A.; Ode, H.; Hoshino, T.; Hata, M.; Ikezaki, A.; Ohgo, Y.; Takahashi, M.; Hiramatsu, H.; Kitagawa, T.; et al. Magnetic and Infrared Properties of the Azide Complex of (2,7,12,17-Tetrapropylporphycenato)iron(III): A Novel Admixing Mechanism of the $S=5 / 2$ and S = 3/2 States. Eur. J. Inorg. Chem. 2007, 2007, 3188-3194. [CrossRef]

Publisher's Note: MDPI stays neutral with regard to jurisdictional claims in published maps and institutional affiliations.

(C) 2020 by the author. Licensee MDPI, Basel, Switzerland. This article is an open access article distributed under the terms and conditions of the Creative Commons Attribution (CC BY) license (http://creativecommons.org/licenses/by/4.0/). 